\title{
THE NEXUS BETWEEN ATTITUDE, SOCIAL NORMS, INTENTION TO COMPLY, FINANCIAL PERFORMANCE, MENTAL ACCOUNTING AND TAX COMPLIANCE BEHAVIOR
}

\section{Hikmah Hikmah ${ }^{1+}$ \\ Priyo Hari Adi ${ }^{2}$ \\ Supramono \\ Supramono $^{3}$ \\ Theresia Woro}

Damayanti $^{4}$

\author{
${ }^{1,3}$ Management Department Universitas Kristen Satya Wacana, Indonesia. \\ Email:hikmah.1967@yahoo.com Tel:+6281325272164. \\ ${ }^{s}$ Email: supramono@uksw.edu Tel: +6285640767117 \\ ${ }^{2,4}$ Accounting Department Universitas Kristen Satya Wacana, Indonesia. \\ ${ }^{2}$ Email:priyo.adi@uksw.edu Tel: +6281329151775 \\ ${ }^{4}$ Email: theresia.damayanti@uksw.edu Tel: +6281326771988
}

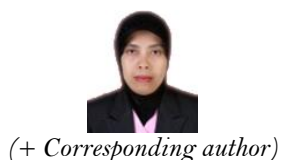

(+ Corresponding author)
Article History

Received: 20 August 2021 Revised: 30 September 2021 Accepted: 25 October 2021 Published: 23 November 2021

\section{Keywords \\ Financial performance \\ Attitude \\ Social norms \\ Intention \\ Mental accounting \\ Tax compliance.}

JEL Classification: M48; G38.

\begin{abstract}
This study empirically investigates the effects of attitudes toward tax compliance, descriptive norms, injunctive norms, subjective norms, personal norms, tax compliance intention, financial performance, and mental accounting on tax compliance. The determinant are largely developed based on the Theory of Planned Behavior (TPB) and social norms. Data collection is carried out through field surveys to obtain a final sample of 209 respondents who are SME owners in 11 regencies/cities in Central Java Province, Indonesia. The data were analyzed using structural equation modeling (SEM). The results show that attitudes toward tax compliance, injunctive norms, subjective norms, personal norms, and financial performance positively affect SME owners' tax compliance intentions. Furthermore, financial performance and tax compliance intentions have a positive effect on tax compliance behavior. However, we do not find empirical evidence that mental accounting has a role in strengthening the effect of tax compliance intentions on tax compliance behavior. This study contributes to the tax compliance literature through a more comprehensive measure of subjective norms and the use of financial performance as an alternative measure of perceived behavioral control.
\end{abstract}

Contribution/Originality: This study contributes to the existing literature relating to crucial aspects of tax compliance by using four dimensions to measure subjective norms and using financial performance as an alternative measure of perceived behavioral control.

\section{INTRODUCTION}

Taxes crucially contribute to state income (Francis, 2019). Unfortunately, data from the OECD (2019) indicates that ASEAN countries have tax revenue levels below the average tax ratios. The United Nations Conference on Trade and Development (2018) disclosed that developing countries have lost about US $\$ 100$ billion of annual tax revenues due to corporate tax evasions. These conditions suggest that low tax compliance remains a serious problem in many countries (Kim, 2008; Loo, Evans, \& McKerchar, 2010).

Tax compliance is not easily defined because it involves many dimensions (Brown \& Mazur, 2003). The behavioral approach suggests that tax compliance represents the behavioral manifestation of taxpayers' behavior. The theory of reasoned actions (Ajzen \& Fishbein, 1975), and the theory of planned behavior as its further 
refinement (Ajzen, 1991), argue that behavior is affected by intention to act. Intention to act integrates attitudes toward behavior, subjective norms, and actors' perceived control (Ajzen 2005).

Several prior studies have shown that tax compliance is influenced by tax compliance intention (Marthadiansyah, Meutia, Mukhtaruddin, \& Saputra, 2013), and intention to comply is consistently affected by attitudes and perceived behavioral control (Bobek \& Hatfield, 2003; Smart, 2012). However, subjective norms do not consistently affect intention to comply. Specifically, several studies demonstrate the significant impact of subjective norms on intention to comply (Benk, Cakmak, \& Budak, 2011; Bobek \& Hatfield, 2003). Others have shown the opposite influence (Marthadiansyah et al., 2013). Prior studies have shown inconsistent results, likely because subjective norms are solely measured with the indicators related to the social environment's effect. Subjective norms are then considered insufficient to analyze one's intention to act (Bobek, Roberts, \& Sweeney, 2007) because of their multidimensional feature. For example, Bobek et al. (2007) and Bobek, Hageman, \& Kelliher (2013) sought to elaborate subjective norms through four dimensions: descriptive norms, injunctive norms, subjective norms, and personal norms. These four norms are often labeled as social norms. Thus, the subjective norm variable needs to be analyzed further in the social norm framework.

Perceived behavioral control is defined as individuals' beliefs about how easy or difficult it is to perform a task, and prior studies have measured perceived behavioral control based on perceptional approach. This study proposes financial performance as another measure to represent perceived behavioral control. Firms with poor financial performance are more motivated to engage in tax evasion (Ayers, Call, \& Schwab, 2018; Feizi, Panahi, Keshavarz, Mirzaee, \& Mosavi, 2016). Conversely, firms with better financial performance tend to report their taxes compliantly (Harinurdin, 2009). Accordingly, better (worse) financial performance ensures taxpayers that tax compliance is easy (difficult). In addition, this study also proposes the role of mental accounting as a variable that moderates the effect of tax compliance intentions on tax compliance. Mental accounting in the context of taxation can be interpreted as an awareness of the taxpayer's thoughts about the allocation of the proceeds of a sale. Every time a sales transaction occurs, the taxpayer's mind immediately remembers that that particular part of the sale must be recorded to pay taxes. Thus, mental accounting by taxpayers is expected to strengthen the effect of the intention to influence tax compliance intentions on tax compliance.

This study seeks to empirically investigate the impacts of attitudes toward tax compliance, social norms (descriptive, injunctive, subjective, and personal), and financial performance on tax compliance intention. This study contributes to the tax compliance literature in the following issues. First, prior tax compliance studies measure subjective norms unidimensionally, while this study refers to Bobek.. et al. (2013) by involving four dimensions to measure the variable. Second, we use financial performance as the alternative measure of perceived behavioral control. Third, this study adds a mental accounting variable that is expected to moderate the effect of tax compliance intentions on tax compliance. Additionally, the results of this study can be used to guide government officials, especially the Directorate General of Taxes, when developing policies to improve tax compliance.

This paper is organized in the following manner: Section 2 contains reviews of prior studies, and hypothesis development; Section 3 explains the research methodology; Section 4 discusses the empirical findings; and the final section concludes the study and offers suggestions.

\section{LITERATURE REVIEW}

\subsection{Theory of Planned Behavior}

As proposed by Ajzen (1991), the Theory of Planned Behavior (TPB) further develops the Theory of Reasoned Action (Ajzen \& Fishbein, 1975). Theory of Reasoned Action suggests that intentions determine behavior; hence, individuals' behavior can be explained by their intentions. Further, Ajzen (1991) uses perceived behavioral control to explain behavior that individuals cannot fully control, although they have positive attitudes 
toward the behavior and others support these behavior. Thus, behavior is jointly affected by intentions and perceived behavioral control. Accordingly, attitudes toward behavior, subjective norms, and perceived behavioral control likely affect tax compliance intention.

Some studies have shown that TPB largely predicts behavioral intention and behavior in various fields including finance (Koropp, Kellermanns, Grichnik, \& Stanley, 2014; Rutherford \& DeVaney, 2009; Xiao, Tang, Serido, \& Shim, 2011) and taxation (Bobek \& Hatfield, 2003; Smart, 2012).

\subsection{Hypothesis Development}

Attitudes toward behavior refer to individuals' evaluation of whether certain behavior leads to favorable or unfavorable outcomes (Ajzen, 1991; Ajzen, 2005; Ajzen, 2011). Meanwhile, Trongmateerut \& Sweeney (2012) emphasize that behavior's favorable consequences tend to increase individuals' intentions to perform the actions. Hence, taxpayers who believe that tax compliance offers favorable consequences are more motivated to be taxcompliant. This argument is supported by prior studies documenting that attitudes toward tax compliance positively affect intention to comply, including in the US (Bobek \& Hatfield, 2003), and in New Zealand and Malaysia (Saad, 2011). Based on the above arguments, we propose the following hypothesis:

\section{$\boldsymbol{H}_{\text {: }}$ Attitudes toward tax compliance positively affect intention to comply.}

Descriptive norms refer to beliefs in others' actual actions (Bobek et al., 2007; Cialdini, Kallgren, \& Reno, 1991). Others' actions tend to guide individuals' actions (Lapinski, Rimal, DeVries, \& Lee, 2005). Consequently, individuals often behave by observing others' behavior (Zuhal, Tansöker, Bayram, \& Aydemir, 2016). When individuals believe that many people engage in a particular behavior, they believe that the behavior is appropriate (Cialdini, 2007). In the context of taxation, taxpayers will intend to pay their taxes if they believe that most other taxpayers around them pay their taxes compliantly. Several studies have demonstrated that intention to comply is affected by descriptive norms, including (Bobek et al., 2007), who studied this issue in three countries: Australia, Singapore, and the US. Based on the above arguments, we propose the following hypothesis:

\section{$\boldsymbol{H}_{\mathrm{s}}$ : Descriptive norms positively affect intention to comply.}

Injunctive norms refer to individuals' beliefs in the extent to which people around them agree or disagree with tax compliance (Bobek et al., 2013). Chung \& Rimal (2016) proposed that injunctive norms refer to individuals' perceptions toward compulsory behavior and that those who do not comply will face social sanctions. Injunctive norms help individuals to determine acceptable and unacceptable behavior. Taxpayers also tend to comply when people around them consider tax compliance to be obligatory and will potentially receive sanctions for incompliant behavior regarding the payment of taxes. Several empirical studies on tax compliance behavior have revealed that injunctive norms greatly affect intention to comply, including (Bobek et al., 2007) and Cai (2014). Based on the above discussion, we propose the following hypothesis:

\section{$\boldsymbol{H}_{s:}$ Injunctive norms positively affect intention to comply.}

Subjective norms refer to social pressures to commit or not to commit a certain behavior faced by individuals (Damayanti, Sutrisno, Subekti, \& Baridwan, 2015). Taxpayers who perceive that pressures from their social environments support tax compliance are more motivated to be tax-compliant than those who perceive that pressures from their social environments do not support tax compliance (Bobek et al., 2007; Bobek et al., 2013; Onu \& Oats, 2015). Prior studies have empirically shown that subjective norms affect tax compliance intention in the US (Bobek \& Hatfield, 2003), Turkey (Benk et al., 2011) and Indonesia (Damayanti et al., 2015). Based on these arguments, the following hypothesis is proposed:

\section{$\mathbf{H}_{4}$ : Subjective norms positively affects intention to comply.}

Personal norms are considered as the basic variable in the psychological model that seeks to determine and define behavior. They represent individuals' moral standards, ethics, or beliefs regarding behavior (Wenzel, 2004). Personal norms refer to individuals' convictions about right or wrong behavior (Zuhal et al., 2016). Taxpayers 
who believe that tax compliance is ethical and right are more motivated to comply with tax rules. Alleyne \& Harris (2017) argued that individuals with greater moral obligations are less likely to intend to evade taxes. Zuhal et al. (2016) suggest that taxpayers voluntarily comply with tax rules when their personal norms and values conform with tax regulations. Taxpayers who believe that reporting taxes compliantly with tax rules is the right thing to do are more motivated to comply. Prior studies, including Bobek et al. (2013), Zuhal et al. (2016) and Onu \& Oats (2015) are consistent with the above argument by documenting that personal norms affect intention to comply. Based on the above discussion, the following hypothesis is proposed:

\section{$\boldsymbol{H}_{5:}$ Personal norms positively affect intention to comply.}

Financial performance measures the results of firms' policies and operations in monetary terms and shows firms' financial health in a certain period ( $\mathrm{Naz} \& \mathrm{Ijaz}, 2016)$. In general, measuring financial performance relies on two indicators: market-based performance and accounting performance (Cochran \& Wood, 1984). However, market-based financial performance is only applicable for publicly listed firms. Conversely, accounting performance - in terms of financial ratios or sales, profit, and cash flow growth - applies to both non-public and publicly listed firms. Firms with better financial performance have greater financing sources to fulfil their financial obligations easily, including tax-related sources. Hence, their managers tend to have greater perceived behavioral control over firms' resources and have greater intentions to comply with tax obligations. Conversely, when a firm has poor financial performance, the managers will tend to be motivated not to comply with tax obligations (Ayers et al., 2018; Feizi et al., 2016; Grant, Taylor, \& Lanis, 2015). A firm's financial performance not only determines its intention to comply with tax payments but also the firm's real actions to fulfil its tax obligations. Several previous studies have proven that there is a link between a company's financial performance and its level of tax compliance (Alm, Liu, \& Zhang, 2019; Kim \& Im, 2016). Accordingly, we propose the following hypothesis:

\section{$\boldsymbol{H}_{6:}$ Financial performance positively affects intention to comply.}

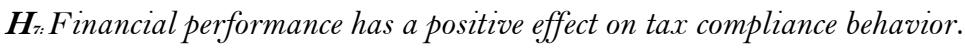

A person's behavior is determined by the intention to perform the behavior (Ajzen, 1991). In the context of behavior to comply with tax payments, several empirical studies have proven that intention to comply affects tax compliance behavior. Bobek \& Hatfield (2003) prove that the intention to comply has an effect on tax compliance behavior. Similar results were empirically proven by Trivedi, Shehata, \& Mestelman (2005) regarding taxpayers in Canada. In Indonesia, research on tax compliance has also proven that the intention to comply affects compliance behavior (Damayanti et al., 2015; Marthadiansyah et al., 2013). Based on the explanation above, the following hypothesis is formulated:

\section{$\boldsymbol{H}_{s:}$ The intention to comply has a positive effect on tax compliance behavior.}

Mental accounting, which was first introduced by Thaler (1985), has several interpretations, including referring to the phenomenon of someone dividing the money earned into several mental accounts. For example, when SME entrepreneurs receive money from the sale of products, they immediately think of putting the money into several mental accounts, such as raw material purchases, employee salaries, and tax payment accounts. Then, SME entrepreneurs will spend money based on the accounts that have been created. Mental accounting can help in controlling one's self in managing income (Muehlbacher, Hartl, \& Kirchler, 2015). Taxpayers who use mental accounting will tend to think about setting aside some of the money they receive to be included in the mental account of tax payments. Thus, if the taxpayer has a high tax compliance intention supported by mental accounting, the taxpayer will have a much higher tax compliance behavior. Based on these arguments, the following hypotheses can be formulated.

\section{$\boldsymbol{H}_{\text {g: }}$ Mental accounting strengthens the effect of tax compliance intentions on tax compliance behavior.}

Based on the formulation of the hypothesis above, a tax compliance model can be developed, as shown in Figure 1. Attitudes toward tax compliance, descriptive norms, injunctive norms, subjective norms, personal norms and financial performance affect the intention to comply. Furthermore, the intention to comply with financial 
performance is expected to affect tax compliance behavior, and mental accounting will also play a role in strengthening the influence of the intention to comply on tax compliance behavior.

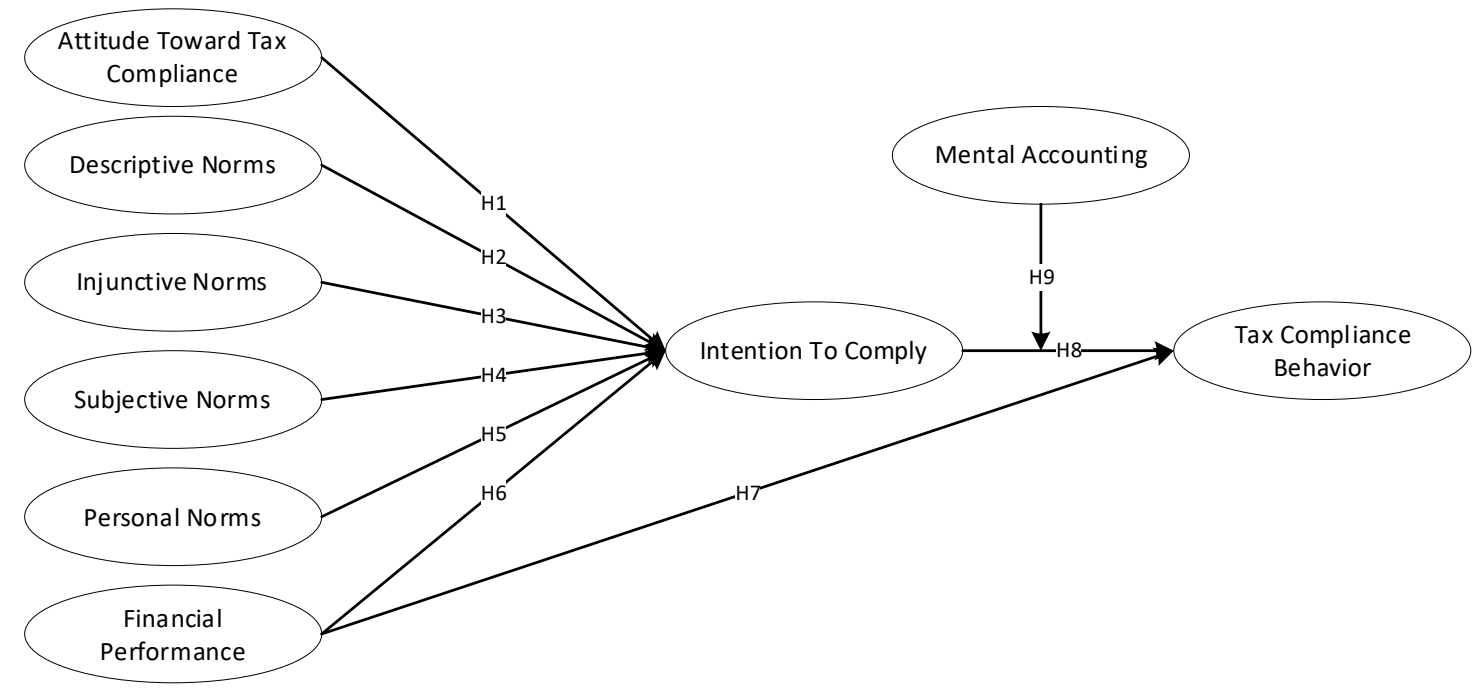

Figure-1. Tax Compliance Model.

\section{METHODS}

\subsection{Population and Sample}

Our study population comprises taxpayers who own SMEs with legal status in Central Java Province, Indonesia. This area is selected because it has many SME centers. This study follows Hair, Black, Babin, \& Anderson (2010) in determining the sample size. In particular, they suggest that the minimum size number must be at least five or ten times the number of empirical indicators.

This study uses a multi-stage sampling (stratified and convenience sampling) method to select the sample. Stratified sampling is used to determine regencies or cities as the basis of sampling selection. Specifically, we stratified cities and regencies based on the 2016 tax ratios of each regency or city in Central Java into three categories: low tax ratio (tax ratio below 0.25 - nine regencies/cities), moderate tax ratio (0.25-0.49 - 20 regencies/cities), and high tax ratio (tax ratio $>0.50$ - four regencies/cities). Eleven regencies/cities were proportionally selected as the research sample with the Microsoft Excel-assisted simple random sampling technique.

The researchers and enumerators distributed the questionnaires from December 2019 to March 2020. From 390 distributed questionnaires, 267 (68.5\%) were returned by April 2020 with 209 usable responses (53.6\% of the total questionnaires). The number of usable responses still meets the specifications stated by Hair et al. (2010).

A detailed analysis of the sample revealed that most respondents are 35-45 years old and have completed senior high school education and bachelor's degrees. Further, most respondents have run their businesses for more than ten years with total assets of between Rp 50,000,000.00 and Rp 500,000,000.00. Following Indonesia's selfassessment system, most respondents perform their tax obligations by themselves.

\subsection{Measurement}

The independent and dependent variables are latent or construct variables that are measured with empirical indicators, as displayed in Table 1. The attitudes toward tax compliance are measured by adopting the method used by Alleyne \& Harris (2017), while we operationalize the variables of descriptive norms, injunctive norms, subjective norms, and personal norms based on Bobek et al. (2013). Further, financial performance is measured by following Maduekwe \& Kamala (2016), who suggest that sales, operating profit, and cashflow growths are 
appropriate to measure SMEs' financial performance. Likewise, with the dependent variable, intention to comply and compliance behavior was developed based on the definition put forward by Damayanti et al. (2015) that intention to comply with tax is a decision to perform tax compliance behavior according to applicable regulations, while compliance behavior is defined as compliance in fulfilling the functions of calculating, paying and reporting taxes. As for the mediating variable, mental accounting is defined as a person's tendency to create mental accounts for the money he earns and will use them according to the accounts he has made.

This study runs the validity test of the construct indicators with the loading factor values. From 39 empirical indicators, four variable indicators have loading factor values below 0.5, namely KK5, SAKP1, ND4, and NI4. These indicators are then discarded because they do not reflect their measured variables' unidimensionality levels. Other indicators have loading factor values between 0.508 and 0.946 , implying that the data is valid. The reliability test reveals that all constructs are reliable because their values are greater than 0.7 (between 0.717 and 0.892).

Table-1. Construct Indicators

\begin{tabular}{|c|c|}
\hline Construct & Indicator \\
\hline \multirow{4}{*}{$\begin{array}{l}\text { Attitudes Toward Tax } \\
\text { Compliance }\end{array}$} & Obligation to calculate taxes based on real sales. \\
\hline & Paying taxes as stipulated is a wise action. \\
\hline & $\begin{array}{l}\text { Taxpayers have to regularly pay taxes no later than the fifteenth day of each } \\
\text { month. }\end{array}$ \\
\hline & Taxpayers have to submit their tax returns no later than April 30. \\
\hline \multirow[t]{4}{*}{ Descriptive Norms } & Most taxpayers deliberately calculate their taxes below the actual amounts. \\
\hline & Most taxpayers pay their taxes differently than the compulsory amounts. \\
\hline & Most taxpayers pay taxes no later than the fifteenth day of each month. \\
\hline & Most taxpayers submit their tax returns no later than April 30. \\
\hline \multirow[t]{4}{*}{ Injunctive Norms } & $\begin{array}{l}\text { Society considers taxpayers calculating their sales below the actual amounts for } \\
\text { tax reporting purposes unacceptable. }\end{array}$ \\
\hline & $\begin{array}{l}\text { Society considers taxpayers paying their taxes differently than the compulsory } \\
\text { amounts unacceptable. }\end{array}$ \\
\hline & $\begin{array}{l}\text { Society considers taxpayers paying their taxes no later than the fifteenth day of } \\
\text { each month unacceptable. }\end{array}$ \\
\hline & $\begin{array}{l}\text { Society considers taxpayers submitting tax returns no later than April } 30 \text { each } \\
\text { year unacceptable. }\end{array}$ \\
\hline \multirow[t]{6}{*}{ Subjective Norms } & $\begin{array}{l}\text { Important individuals will disagree with calculating sales lower than the actual } \\
\text { amounts for tax reporting purposes. }\end{array}$ \\
\hline & $\begin{array}{l}\text { Important individuals will agree with paying taxes no later than the fifteenth day } \\
\text { of each month. }\end{array}$ \\
\hline & Important individuals will agree to submit tax returns no later than April 30. \\
\hline & $\begin{array}{l}\text { People around me perceive calculating sales lower than the actual amounts for } \\
\text { tax reporting purposes negatively. }\end{array}$ \\
\hline & People around me perceive paying taxes late negatively. \\
\hline & People around me perceive submitting tax returns late negatively. \\
\hline \multirow[t]{4}{*}{ Personal Norms } & $\begin{array}{l}\text { I feel guilty if I calculate my sales lower than the actual amounts for tax } \\
\text { reporting purposes. }\end{array}$ \\
\hline & I feel ashamed if I pay taxes differently than the compulsory amounts. \\
\hline & I feel guilty if I pay taxes later than the fifteenth day of each month. \\
\hline & I feel happy if I submit my tax return no later than April 30 each year. \\
\hline \multirow[t]{5}{*}{ Financial Performance } & Increased sales. \\
\hline & Sales are greater than costs incurred. \\
\hline & I can set aside increased income to develop my business. \\
\hline & My cash receipts are always greater than my cash expenditures. \\
\hline & Increased cash receipts. \\
\hline \multirow[t]{4}{*}{ Intention to Comply } & I always try to calculate my taxes based on the actual sales. \\
\hline & I do not intend to pay taxes differently from the actual amounts. \\
\hline & I plan to pay taxes no later than the fifteenth day of each month. \\
\hline & I plan to submit my tax return before April 30 each year. \\
\hline
\end{tabular}




\begin{tabular}{l|l}
\hline Construct & Indicator \\
\hline Mental Accounting & When a sale occurs, I think about the obligation to pay taxes. \\
\hline \multirow{4}{*}{$\begin{array}{l}\text { Tax Compliance } \\
\text { Behavior }\end{array}$} & $\begin{array}{l}\text { Every time a sale occurs, I think about the amount of tax that must be paid. } \\
\text { of paying taxes. }\end{array}$ \\
\cline { 2 - 2 } & $\begin{array}{l}\text { Includes people who do not find it easy to use the money for purposes other than } \\
\text { what is planned. }\end{array}$ \\
\hline \multirow{2}{*}{} & Compliance with tax calculations. \\
\hline & Compliance with tax payments. \\
\cline { 2 - 2 } & Compliance with tax payment deadline. \\
\cline { 2 - 2 } & Compliance with the submission of annual tax returns. \\
\hline
\end{tabular}

\subsection{Analytical Model}

This study tests the hypotheses using structural equation modeling (SEM). First, the determinants of the intention to comply are examined in Equation 1. Then, the determinants of tax compliance are examined in Equation 2, and the effect of moderating variables on tax compliance is examined in Equation 3.

$$
\begin{gathered}
\mathrm{IC}=\beta 1 \mathrm{ATC}+\beta 2 \mathrm{DN}+\beta 3 \mathrm{IN}+\beta 4 \mathrm{SN}+\beta 5 \mathrm{PN}+\beta 6 \mathrm{FP}+\delta 1 \\
\mathrm{TCB}=\beta 7 \mathrm{FP}+\beta 8 \mathrm{IC}+\delta 2 \\
\mathrm{TCB}=\beta 9 \mathrm{IC}+\beta 10 \mathrm{MA}+\beta 11 \mathrm{NUP} * \mathrm{MA}+\delta 3
\end{gathered}
$$

where: $\beta=$ regression coefficients; $\delta=$ error term; ATC $=$ attitudes toward tax compliance; DN $=$ descriptive norms; IN = injunctive norms; $\mathrm{SN}=$ subjective norms; $\mathrm{PN}=$ personal norms; $\mathrm{FP}=$ financial performance; IC = intention to comply; $\mathrm{TCB}=$ tax compliance behavior; $\mathrm{MA}=$ mental accounting.

\section{RESULTS}

\subsection{Descriptive Statistics}

Table 2 illustrates the descriptive statistics of the research constructs (attitudes toward tax compliance, descriptive norms, injunctive norms, subjective norms, personal norms, financial performance, intention to comply, tax compliance behavior, and mental accounting). On average, respondents' answers are in the $>5.48-5.77$ interval for all constructs. The responses indicate that respondents agree with these constructs.

Table 2. Descriptive Statistics.

\begin{tabular}{l|c|c|c|c|c}
\hline Explanation & N. & Min. & Max. & Mean & Std. Deviation \\
\hline Attitudes Toward Tax Compliance & 209 & 1 & 7 & 5.64 & 0.95 \\
\hline Descriptive Norms & 209 & 2 & 7 & 5.77 & 0.98 \\
\hline Injunctive Norms & 209 & 1 & 7 & 5.48 & 1.13 \\
\hline Subjective Norms & 209 & 1 & 7 & 5.50 & 1.06 \\
\hline Personal Norms & 209 & 2 & 7 & 5.45 & 0.98 \\
\hline Financial Performance & 209 & 1 & 7 & 5.46 & 1.16 \\
\hline Intention to Comply & 209 & 1 & 7 & 5.53 & 1.11 \\
\hline Tax Compliance Behavior & 209 & 2 & 7 & 5.53 & 0.90 \\
\hline Mental Accounting & 209 & 2 & 7 & 5.52 & 0.90 \\
\hline
\end{tabular}

\subsection{Hypothesis Testing}

After running a series of data fit, normality, multicollinearity, and heteroscedasticity tests, further tests were carried out to obtain a fit model. Table 3 below shows the final results of the goodness of fit (GoF) test. 
Table 3. Full Model Structural Goodness of Fit.

\begin{tabular}{|c|c|c|c|c|}
\hline GOF Index & Assessment Criteria & & Estimation & Model \\
\hline $\begin{array}{l}\text { Chi-square } \\
\left(\mathrm{X}^{2}\right)\end{array}$ & $\begin{array}{l}0 \leq \mathrm{X}^{2} \leq 2 \mathrm{df} \\
2 \mathrm{df}<\mathrm{X}^{2} \leq 2 \mathrm{df}\end{array}$ & $\begin{array}{l}\rightarrow \text { Good } \\
\rightarrow \text { Acceptable }\end{array}$ & 606.065 & Good \\
\hline Probability & $\begin{array}{l}0.05 \leq \mathrm{p} \leq 1.00 \\
0.01<\mathrm{p}<0.05\end{array}$ & $\begin{array}{l}\rightarrow \text { Good } \\
\rightarrow \text { Acceptable }\end{array}$ & 0.012 & Acceptable \\
\hline GFI & $\begin{array}{l}\text { GFI }>0.90 \\
0.80<\text { GFI }<0.90\end{array}$ & $\begin{array}{l}\rightarrow \text { Good } \\
\rightarrow \text { Acceptable }\end{array}$ & 0.854 & Acceptable \\
\hline AGFI & $\begin{array}{l}\text { AGFI }>0.89 \\
0.80<\text { AGFI }<0.89\end{array}$ & $\begin{array}{l}\rightarrow \text { Good } \\
\rightarrow \text { Acceptable }\end{array}$ & 0.827 & Acceptable \\
\hline TLI & $\begin{array}{l}\text { TLI } \geq 0.95 \\
0.80<\mathrm{TLI}<0.97\end{array}$ & $\begin{array}{l}\rightarrow \text { Good } \\
\rightarrow \text { Acceptable }\end{array}$ & 0.964 & Good \\
\hline CFI & $\begin{array}{l}\mathrm{CFI} \geq 0.95 \\
0.80<\mathrm{CFI}<0.97\end{array}$ & $\begin{array}{l}\rightarrow \text { Good } \\
\rightarrow \text { Acceptable }\end{array}$ & 0.968 & Good \\
\hline $\mathrm{CMIN} / \mathrm{DF}$ & $\begin{array}{l}0 \leq \mathrm{CMIN} / \mathrm{DF} \leq 2 \\
2<\mathrm{CMIN} / \mathrm{DF} \leq 3\end{array}$ & $\begin{array}{l}\rightarrow \text { Good } \\
\rightarrow \text { Acceptable }\end{array}$ & 1.144 & Good \\
\hline RMSEA & $\begin{array}{l}0.05<\mathrm{RMSEA} \leq 0.08 \\
0<\mathrm{RMSEA} \leq 0.05\end{array}$ & $\begin{array}{l}\rightarrow \text { Good } \\
\rightarrow \text { Very Good }\end{array}$ & 0.028 & Very Good \\
\hline
\end{tabular}

The full-model SEM is considered fit or good when the chi-square, probability value fit index, GFI, AGFI, TLI, CFI, CMIN/DF, and RMSEA are within the expected ranges. Table 4 shows the results of the hypothesis testing.

Table 4. The results of hypothesis testing.

\begin{tabular}{|c|c|c|c|c|c|c|c|c|}
\hline $\mathbf{H}$ & \multicolumn{3}{|c|}{ Influence } & $\begin{array}{c}\text { Std. } \\
\text { Estimate }\end{array}$ & StandardError & $\begin{array}{c}\text { Critical } \\
\text { Ratio }\end{array}$ & P-value & Explanation \\
\hline 1 & $\mathrm{IC}$ & $<--$ & ATC & 0.244 & 0.120 & 2.576 & $0.010^{* * *}$ & Supported \\
\hline 2 & $\mathrm{IC}$ & $<--$ & $\mathrm{DN}$ & 0.114 & 0.101 & 1.240 & 0.215 & $\begin{array}{c}\text { Not } \\
\text { Supported }\end{array}$ \\
\hline 3 & $\mathrm{IC}$ & $<---$ & IN & 0.324 & 0.122 & 3.406 & $0.000^{* * * *}$ & Supported \\
\hline 4 & $\mathrm{IC}$ & $<---$ & SN & 0.169 & 0.086 & 2.233 & $0.026^{* * *}$ & Supported \\
\hline 5 & $\mathrm{IC}$ & $<---$ & $\mathrm{PN}$ & 0.178 & 0.092 & 2.010 & $0.044^{* * *}$ & Supported \\
\hline 6 & IC & $<---$ & $\mathrm{FP}$ & 0.172 & 0.067 & 2.220 & $0.026^{* *}$ & Supported \\
\hline 7 & TCB & $<<--$ & $\mathrm{FP}$ & 0.335 & 0.066 & 3.799 & $0.000^{* * * * *}$ & Supported \\
\hline 8 & TCB & $<---$ & IC & 0.292 & 0.082 & 3.114 & $0.002^{* * * *}$ & Supported \\
\hline 9 & TCB & $<--$ & Interaction ICxMA & -0.797 & 0.052 & -9.945 & $0.000^{*} * * *$ & $\begin{array}{c}\text { Not } \\
\text { Supported }\end{array}$ \\
\hline
\end{tabular}

As displayed in Table 4, the regression coefficient and probability values imply that seven hypotheses are supported and two are not supported. The result of Hypothesis 1 indicates the positive impact of attitudes toward compliance $(\beta=0.244 ; p=0,0010)$ on the intention to comply. Our empirical finding supports the Theory of Planned Behavior, which suggests that attitudes toward behavior affect the intention to behave (Ajzen, 1991), on the tax compliance framework. SME owner-managers positively evaluate tax compliance behavior, i.e., calculating, paying, and reporting tax obligations. Positive evaluation implies that SME owners perceive that engaging in tax compliance behavior will lead to favorable consequences. Consequently, they have greater intentions to be tax-compliant. This is in line with Trongmateerut \& Sweeney (2012), who have proven that certain behaviors' favorable consequences tend to enhance individuals' intentions to engage in such behavior. Our empirical study also supports Saad (2011), Bobek \& Hatfield (2003) and Trivedi et al. (2005). Hypothesis 2 states that the positive effect of descriptive norms on the intention to comply is not empirically supported $(p=0.215)$. Hence, individuals' behavior is not associated with tax compliance. Descriptive norms, which are individuals' beliefs that arise from observing other people's behavior, cannot encourage the intention to comply, allegedly due to at least two things. First, tax compliance behavior itself is not a behavior that can be easily observed (Bobek et 
al., 2007), so it can lead to a bias in one's belief towards the tax compliance behavior of others. Second, violating descriptive norms may not have any social impact (Chung \& Rimal, 2016), especially in Indonesia where there is a collectivism culture, so they pay more attention to social aspects rather than individual beliefs. Testing for Hypothesis 3 found that injunctive norms positively affect intention to comply $(\beta=0.324 ; p=0.000)$. This means that greater injunctive norms cause taxpayers to have greater tax compliance intention than SME owners with lower injunctive norms. Tax compliance behavior is publicly supported, as is socially sanctioning people who are not tax-compliant. This encourages SME owners as taxpayers to have a high intention to comply. This empirical finding is also consistent with Bobek et al. (2007) and Cai (2014).

Hypothesis 4 testing also empirically indicates the positive effect of subjective norms on the intention to comply ( $\beta=0.169 ; p=0.026$ ). This finding supports Damayanti et al. (2015), Bobek et al. (2013), Benk et al. (2011), Bobek et al. (2007), and Bobek \& Hatfield (2003). The finding shows that SME owners with better perceptions of subjective norms have greater tax compliance behavior (calculating, paying, and reporting taxes) than SME owners with lower perceptions of subjective norms. The empirical evidence demonstrates that families, parents, friends, business partners, and employees support SME owners' compliance with tax rules.

Our test on Hypothesis 5 supports the idea that personal norms positively affect intention to comply $(\beta=$ $0.178 ; p=0.044)$. This finding is similar to Zuhal et al. (2016), who documented that taxpayers will comply with tax regulations voluntarily when their personal norms and values comply with tax rules. SME owners with greater beliefs that tax compliance is the right behavior will have higher tax compliance intention (calculating, paying, and reporting taxes) than those with lower beliefs that tax compliance is the right behavior.

The statistical test also confirms that better financial performance motivates SME owner-managers to have greater tax compliance intention $(\beta=0.172 ; p=0.026)$. As suggested by Ajzen (1991), individuals who believe that they have access to important resources and more opportunities to act tend to have greater intention. It is easier for SME owners with better financial performance to have tax compliance intention. SMEs with better financial performance have greater financing sources to fulfil their tax obligations easily. This empirical evidence also supports various prior studies (e.g., Bobek \& Hatfield, 2003; Trivedi et al., 2005). Testing Hypothesis 7 also provided empirical evidence that financial performance affects tax compliance behavior in a positive direction $(\beta=$ $0.335 ; \mathrm{p}=0.000)$. This result can be interpreted that firms with good financial performance will have a larger source of corporate financing, so they tend to report their taxes honestly. Thus, the results of this study are in line with the studies of Kim \& Im (2016) and Alm et al. (2019), which show that good financial performance affects tax compliance behavior. Testing Hypothesis 8 shows that the intention to comply has a positive and significant effect on tax compliance behavior $(\beta=0.292 ; \mathrm{p}=0.002)$. The results of this study indicate that $\mathrm{SME}$ owners who have a high intention to comply will make the decision to behave as good citizens and fulfill their tax obligations. Additionally, the results of this study support the results of previous studies, namely Marthadiansyah et al. (2013) and Trivedi et al. (2005). The test results on the role of mental accounting as a moderating variable were not proven to significantly strengthen the effect of intention to comply with tax compliance behavior $(\beta=-0.797$; $\mathrm{p}<$ 0.01). The results of this study indicate that mental accounting weakens the effect of the intention to comply with tax compliance behavior. It is possible that SME owners already have the mental awareness to set aside some of their income to pay taxes, but in reality, it is used to procure raw materials, auxiliary materials, or fulfill other needs that they feel are more urgent. This is inseparable from the condition that most SMEs have financial constraints (Hidayati, Moeljadi, \& Djazuli, 2014; Mazzarol, 2014; Mungal \& Garbharran, 2014).

\section{CONCLUSION AND RECOMMENDATIONS}

Our empirical results show that the factors suggested by the Theory of Planned Behavior and social norms are proven to influence the tax compliance intentions of SMEs in Indonesia. These factors include attitudes towards tax compliance, binding norms, subjective norms, personal norms, and financial performance. 
Furthermore, the intention to comply and financial performance will determine whether a taxpayer complies with his tax obligations or not. However, our empirical findings do not document any significant effect of one of the dimensions of social norms, namely descriptive norms, on the intention to comply. In addition, mental accounting, which is expected to act as a moderating variable, is not proven to strengthen the effect of intention to comply with taxes on tax compliance behavior. The results imply that the government (through its tax authority) needs to build public trust and ensure that taxpayers' taxes will be used to improve public welfare. Consequently, the public will have a better understanding that taxes are from the people and for the people. Eventually, Indonesian SME owners will have more positive attitudes toward taxes. Additionally, the findings that indicate the significant effects of injunctive norms, subjective norms, and personal norms on the intention to comply informs the tax authority that they need to improve taxpayers' and SME owners' perceptions that fulfilling tax obligations in a timely manner (paying taxes and submitting tax returns) is obligatory. Furthermore, the tax authority needs to ensure that SME owners and their peers that the tax authority has sufficient resources to detect tax evasion and place sanctions on tax evaders. The findings demonstrate that SME owners have greater intentions to be taxcompliant when they perform well financially. Thus, the tax authority needs to act on these findings by educating taxpayers, especially SME owners, that taxes paid are not just expenses, but that they will eventually stimulate the economy to benefit SME owners through increased demand. This study does not document a significant effect of descriptive norms on the intention to comply. It is then likely that descriptive norms do not affect the intention to comply directly, but indirectly through intervening or moderating variables. Accordingly, we suggest that future studies should develop the TPB model further by positioning the social norms consisting of four constructs as the variables that directly and indirectly affect intention to comply. Moreover, the results of this study indicate that mental accounting actually weakens the effect of tax compliance intentions on tax compliance. It is possible, that even though SME owners already use mental accounting, or because they are facing financial constraints, part of the income that is set aside to pay taxes is used to meet other needs instead. Therefore, future research can address the effect of mental accounting interaction with financial performance on tax compliance behavior.

Funding: This study received no specific financial support.

Competing Interests: The authors declare that they have no competing interests.

Acknowledgement: All authors contributed equally to the conception and design of the study.

\section{REFERENCES}

Ajzen, I., \& Fishbein, M. (1975). A Bayesian analysis of attribution processes. Psychological Bulletin, 82(2), $261-277$.

Ajzen, I. (1991). The theory of planned behavior. Organizational Behavior and Human Decision Processes, 50(2), $179-211$.

Ajzen, I. (2005). Attitudes, personality, and behavior (2nd ed.). New York: Open University Press. MacGraw Hill.

Ajzen, I. (2011). The theory of planned behaviour: Reactions and reflections. Psychology and Health, 26(9), 1113-1127. Available at: https://doi.org/10.1080/08870446.2011.613995.

Alleyne, P., \& Harris, T. (2017). Antecedents of taxpayers' intentions to engage in tax evasion: Evidence from Barbados. Journal of Financial Reporting and Accounting, 15(1), 2-21. Available at: https://doi.org/10.1 108/JFRA-12-2015-0107.

Alm, J., Liu, Y., \& Zhang, K. (2019). Financial constraints and firm tax evasion. International Tax and Public Finance, $26,71-102$. Available at: https://doi.org/10.1007/s10797-018-9502-7.

Ayers, B. C., Call, A. C., \& Schwab, C. M. (2018). Do analysts' cash flow forecasts encourage managers to improve the firm's cash flows? Evidence from tax planning. Contemporary Accounting Research, 35(2), 767-793. Available at: https://doi.org/10.1111/1911-3846.12403.

Benk, S., Cakmak, A. F., \& Budak, T. (2011). An investigation of tax compliance intention: A theory of planned behavior approach. European Journal of Economics, Finance and Administrative Sciences, 28(28), 180-188. 
Bobek, D. D., \& Hatfield, R. C. (2003). An investigation of the theory of planned behavior and the role of moral obligation in tax compliance. Behavioral Research in Accounting, 15(1), 13-36. Available at: https://doi.org/10.2308/bria.2003.15.1.13.

Bobek, D. D., Roberts, R. W., \& Sweeney, J. T. (2007). The social norms of tax compliance: Evidence from Australia, Singapore, and the United States. Journal of Business Ethics, 74(1), 49-64. Available at: https://doi.org/10.1007/s 10551-006-9219$\mathrm{x}$.

Bobek, D. D., Hageman, A. M., \& Kelliher, C. F. (2013). Analyzing the role of social norms in tax compliance behavior. Journal of Business Ethics, 115 (3), 451-468. Available at: https://doi.org/10.1007/s 10551-012-1390-7.

Brown, R., \& Mazur, M. (2003). IRS's comprehensive approach to compliance. Paper presented at the The National Tax Association Spring Symposium.

Cai, Y. (2014). Social Norm and its influence on tax compliance. Senior Theses, Trinity College, Hartford.

Chung, A., \& Rimal, R. N. (2016). Social norms: A review. Review of Communication Research, 4, 1-28. Available at: https://doi.org/10.12840/issn.2255-4165.2016.04.01.008.

Cialdini, R. B., Kallgren, C. A., \& Reno, R. R. (1991). A focus theory of normative conduct: A theoretical refinement and reevaluation of the role of norms in human behavior. Advances In Experimental Social Psychology, 24, 201-234. Available at: https://doi.org/10.1016/s0065-2601(08)60330-5.

Cialdini, R. B. (2007). Descriptive social norms as underappreciated sources of social control. Psychometrika, 72(2), $263-268$. Available at: https://doi.org/10.1007/s11336-005-1495-y.

Cochran, P. L., \& Wood, R. A. (1984). Corporate social responsibility and financial performance. Academy of Management Journal, $27(1), 42-56$.

Damayanti, T. W., Sutrisno, T., Subekti, I., \& Baridwan, Z. (2015). The role of taxpayer's perception of the government and society to improve tax compliance. Accounting and Finance Research, 4(1), 180-187. Available at: https://doi.org/10.5430/afr.v4n1p180.

Feizi, M., Panahi, E., Keshavarz, F., Mirzaee, S., \& Mosavi, S. M. (2016). The impact of the financial distress on tax avoidance in listed firms: Evidence from Tehran Stock Exchange ( TSE ). International Journal of Advanced Biotechnology and Research, 7(1), 373-382.

Francis, O. (2019). The influence of tax amnesty programme on tax compliance in Nigeria: The moderating role of political trust. Journal of Accounting and Taxation, 11 (7), 120-129. Available at: https://doi.org/10.5897/jat2019.0349.

Grant, R., Taylor, G., \& Lanis, R. (2015). The impact of financial distress on corporate tax avoidance spanning the global financial crisis: Evidence from Australia. Economic Modelling, 44, 44-53. Available at: https://doi.org/10.1016/j.econmod.2014.09.015.

Hair, J. F., Black, W. C., Babin, B. J., \& Anderson, R. E. (2010). Multivariate data analysis (7th ed.). New Jersey: Prentice Hall International Inc.

Harinurdin, E. (2009). Corporate taxpayer compliance behavior. Journal of Administrative and Organizational Sciences, 16(2), 96104.

Hidayati, S. A., Moeljadi, D., \& Djazuli, A. (2014). Behavioural finance and its impact on corporate performance (study on small and medium enterprises In Lombok Island). International Journal of Business and Management Invention (IJBMI), 3(5\|), $18-25$.

Kim, S. (2008). Does political intention affect tax evasion? Journal of Policy Modeling, 30(3), 401-415. Available at: https://doi.org/10.1016/j.jpolmod.2007.12.004.

Kim, J. H., \& Im, C. C. (2016). Corporate tax avoidance in SME: The effect of listing. International Journal of u- and e- Service, Science and Technology, 9(6), 283-294. Available at: http://dx.doi.org/10.14257/ijunesst.2016.9.6.26.

Koropp, C., Kellermanns, F. W., Grichnik, D., \& Stanley, L. (2014). Financial decision making in family firms: An adaptation of the theory of planned behavior. Family Business Review, 27(4), 307-327. Available at: https://doi.org/10.1177/0894486514522483. 
Lapinski, M. K., Rimal, R. N., DeVries, R., \& Lee, E. L. (2005). An explication of social norms communication theory volume. Communication Theory, 15(2), 127-147. Available at: https://doi.org/10.1111/j.1468-2885.2005.tbo0329.x.

Loo, E. C., Evans, C., \& McKerchar, M. (2010). Challenges in understanding compliance behaviour of taxpayers in Malaysia. Asian Journal of Business and Accounting, 3(2), 101-118. Available at: https://doi.org/10.1257/app.20160597.

Maduekwe, C. C., \& Kamala, P. (2016). Performance measurement by small and medium enterprises in Cape Metropolis, South Africa. Problems and Perspectives in Management, 14(2), 46-55. Available at: https://doi.org/10.21511/ppm.14(2).2016.05.

Marthadiansyah, Meutia, I., Mukhtaruddin, \& Saputra, D. (2013). Empirical study of tax payer compliance in tax filing: applying theory planned of behavior. Paper presented at the Annual International Conference on Accounting And Finance.

Mazzarol, T. (2014). Financial management in SMEs. Small Enterprise Research., 21(1), 2-13.

Muehlbacher, S., Hartl, B., \& Kirchler, E. (2015). Mental accounting and tax compliance : Experimental evidence for the effect of mental segregation of tax due and revenue on compliance. Public Finance Reviere, 45(1), 118-139. Available at: https://doi.org/10.1177/1091142115602063.

Mungal, A., \& Garbharran, H. L. (2014). The perceptions of small businesses in the implementation of cash management techniques. Journal of Economics and Behavioral Studies, 6(1), 75-83. Available at: https://doi.org/10.22610/jebs.v6i1.471.

Naz, F., \& Ijaz, F. (2016). Financial performance of firms: Evidence from Pakistan cement financial Industry. Journal of Teaching and Education, 5(1), 81-94.

OECD. (2019). Global forum on transparency and exchange of information for tax purposes. Paris: OECDilibrary.

Onu, D., \& Oats, L. (2015). The role social norms and tax compliance: Theoretical overview and practical implications. Journal of Tax Administration, 1(1), 113-137.

Rutherford, L., \& DeVaney, S. A. (2009). Utilizing the theory of planned behavior to understand convenience use of credit cards. Journal of Financial Counseling and Planning, 20(2), 48-63.

Saad, N. (2011). Fairness perceptions and compliance behaviour: taxpayers' judgments in Self assessment environments. Thesis the Degree of Doctor of Philosophy in Taxation in the University of Canterbury.

Smart, M. (2012). The application of the theory of planned behaviour and structural equation modelling in tax compliance behaviour: $A$ New Zealand Study. Thesis University of Canterbury of Doctor of Philosophy in Taxation.

Thaler, R. (1985). Mental accounting and consumer choice. Marketing Science, 4(3), 199-2 14.

Trivedi, V. U., Shehata, M., \& Mestelman, S. (2005). Attitudes, incentives, and tax compliance. Canadian Tax Journal, 53(1), 2961.

Trongmateerut, P., \& Sweeney, J. T. (2012). The influence of subjective norms on whistle-blowing: A cross-cultural investigation. Journal of Business Ethics, 112(3), 437-451. Available at: https://doi.org/10.1007/s10551-012-1270-1.

United Nations Conference on Trade and Development. (2018). World investment report 2018. Paper presented at the Investmetn and New Industrial Policies In United Nations Conference on Trade and Development', Jenewa.

Wenzel, M. (2004). An analysis of norm processes in tax compliance. Journal of Economic Psychology, 25, 213-228. Available at: https://doi.org/10.1016/S0167-4870(02)00168-X.

Xiao, J. J., Tang, C., Serido, J., \& Shim (2011). Antecedents and consequences of risky credit behavior among college students : Application and extension of the theory of planned behavior. Handbook of Consumer Finance Research, 30(2), $239-245$. Available at: https://doi.org/10.2307/23209278.

Zuhal, Y., Tansöker, R. L., Bayram, N., \& Aydemir, M. (2016). A structural equation modeling the role of social norms in tax compliance: A study from Turkey. International Journal of Humanities and Social Science Invention, 5(12), 81-89.

Views and opinions expressed in this article are the views and opinions of the author(s), Asian Economic and Financial Review shall not be responsible or answerable for any loss, damage or liability etc. caused in relation to/arising out of the use of the content. 